Jurnal Pendidikan Matematika Indonesia is licensed under A Creative Commons Attribution-Non Commercial 4.0 International License.

\title{
EFEKTIVITAS PEMBELAJARAN MATEMATIKA MELALUI PENERAPAN MODEL KOOPERATIF TIPE STUDENT FACILITATOR AND EXPLAINING (SFAE)
}

\author{
Wahyuddin $^{1)}$, Ita Wahyuni Yusuf ${ }^{2)}$ \\ 1) Universitas Muhammadiyah Makassar \\ E-mail: wahyu@unismuh.ac.id \\ 2) Universitas Muhammadiyah Makassar \\ E-mail: itawahyuniyusuf@unismuh.ac.id
}

\begin{abstract}
Abstrak. Penelitian ini merupakan penelitian kuantitatif dengan pendekatan eksperimen pre-experimental design yaitu one-group pretest-posttest design yang bertujuan untuk mendeskripsikan keefektifan penerapan model kooperatif tipe student facilitator and explaining. Satuan eksperimen yaitu kelas VII A.2 yang dipilih secara random dari 4 kelas dengan perlakuan sebanyak 4 kali pertemuan. Instrumen penelitian terdiri atas tes hasil belajar, lembar observasi aktivitas siswa, angket respon siswa dan lembar observasi keterlaksanaan pembelajaran. Analisis data yang digunakan adalah teknik analisis statistik deskriptif untuk menggambarkan hasil belajar matematika, aktivitas siswa, serta respon siswa dan statistik inferensial yaitu one sample t-test dengan uji normalitas yang dilanjutkan dengan pengujian hipotesis. Hasil penelitian menyimpulkan bahwa model kooperatif tipe student facilitator and explaining efektif diterapkan pada siswa kelas VII SMP Unismuh Makassar dengan indikator : 1) Hasil belajar setelah diterapkan tindakan berada dalam kategori sedang dengan skor rata-rata 79,60, standar deviasi 12,11 dan mencapai ketuntasan belajar secara klasikal; 2) Dalam proses pembelajaran aktivitas siswa berada pada kategori aktif yaitu sebanyak 76,42; dan 3) Siswa pada umumnya memberikan tanggapan positif sebanyak $82,21 \%$ siswa.
\end{abstract}

Kata Kunci: Efektivitas Pembelajaran, Kooperatif, dan Student Facilitator And Explaining, dan Eksprimen.

\section{PENDAHULUAN}

Matematika adalah kunci dalam memanfaat semua peluang. Matematika tidak lagi hanya sebatas bahasa sains, matematika berkontribusi secara langsung dan mendasar untuk bisnis, keuangan, kesehatan, pertahanan, dan bahkan semua bidang. Bagi siswa, matematika membuka pintu bagi kariernya karena mengarahkan dalam pengambilan keputusan berdasarkan informasi, dan memberikan pengetahuan untuk bersaing dalam komunitas teknologi (Council, 1989). Lebih lanjut, Wahyuddin, (2017) menjelaskan bahwa melalui kaidah matematika dapat digunakan sebagai alat untuk memecahankan masalah yang dihadapi dalam berbagai problemitaka dalam kehidupan.

Hashomoto (1997) mengatakan bahwa pembelajaran matematika memiliki potensi dalam mengembangkan kemampuan berpikir kreatif siswa, mendorong siswa untuk secara kreatif mengeksplorasi berbagai jalan keluar dari masalah yang dihadapi. Selanjutnya Becker dan Shimada menjelaskan bahwa pembelajaran matematika memungkinkan masalah terbuka dapat diselesaikan dengan berbagai jawaban,
(Livne, 2008).

Peran matematika sangat penting karena melintasi berbagai disiplin ilmu dalam sains, teknologi dan matematika (STM). Pemahaman dalam matematika dikenal untuk memfasilitasi pencapaian dalam fisika, kimia, biologi, mekanika dan teknik. Dengan demikian, matematika harus dibuat menyenangkan sedemikian rupa sehingga dipahami dengan baik oleh siswa sehingga mereka dapat berprestasi dan sukses dalam bidang yang mereka geluti (Tsafe, 2012). Berdasarkan hal tersebut sehingga dalam pembelajaran matematika perlu penekanan pendekatan scientific agar pembelajaran bermakna melalui kegiatan mencoba, mengamati, menyaji, menalar, menanya, dan mencipta sehingga dalam diri semua peserta tertanam kemampuan bekerja sama, berpikir logis kemampuan kritis, kreatif, sistematis, dan analitis.

Oleh karena itu, matematika ini perlu dipahami oleh siswa. Namun kenyataan yang terjadi tidak sesuai dengan apa yang menjadi harapan bersama, dari hasil wawancara dengan siswa yang sebagian besar mengatakan bahwa siswa memiliki banyak kesalahan dalam menyelesaikan soal, siswa merasa kurang mampu dan tidak tertarik dengan alasan tidak menyukainya. 
Adapun permasalahan umum yang sering dijumpai di SMP antara lain adalah tidak adanya inisiatif peserta didik untuk bertanya, peserta didik hanya menjawab pertanyaan dari guru secara individu namun tidak berani bertanya dan mengeluarkan pendapat sendiri, peserta didik berbicara sendiri ketika guru menerangkan atau mengajar, serta kemandirian dalam mengerjakan soal masih sangat kurang (Solikhin \& Mustakim, 2015).

Permasalahan tersebut juga terjadi di SMP Unismuh Makassar. Berdasarkan observasi awal diperoleh informasi bahwa rata-rata UN matematika SMP Unismuh Makassar sebesar 39,53 lebih rendah dibandingkan dengan hasil ujian nasional matematika di di provinsi Sulawesi Selatan dengan rata-rata 51,65 dan UN nasional dengan rata-rata 47,75. Lebih lanjut, data hasil ujian semester ganjil tahun 2018/2019 terdapat $60 \%$ siswa yang hasil belajar matematikanya berada di bawah KKM yaitu 75,00. Informasi dari guru mata pelajaran matematika yang diperoleh melalui wawancara bahwa rendahnya hasil belajar matematika pada sekolah tersebut disebabkan karena materi yang menjadi bahan pelajaran seakan tidak bermakna bagi siswa, siswa merasa bahwa belajar matematika hanya sebatas perhitungan yang tidak dipahami kapan akan diaplikasikan dan pengaplikasiannya bagaimana sehingga siswa kurang antusian dalam belajar, siswa sudah didotring menjadi pendengar setia, dan hanya menerima informasi apa yang disampaikan oleh guru, dalam mengemukakan pendapat juga sangat jarang. Hal ini dikarenakan siswa tidak memiliki keberanian untuk bertanya pada guru.

Masalah lain yaitu permasalahan yang timbul dari diri sendiri siswa misalnya tidak percaya diri, pikiran negatif terhadap matematika, kurang menguasai perhitungan, kesalahan dalam menyelesaikan soal, pengetahuan siswa tentang matematika hanya diingat selama siswa masih dalam kelas dan setelah keluar dari kelas mereka sudah lupa tentang apa yang mereka telah pelajari. Selain dianggap sebagai pelajaran yang sulit, masalah dalam pembelajaran matematika juga terkait dengan kurangnya keterampilan regulasi di antara siswa dalam belajar matematika. Siswa melihat mata pelajaran matematika yang tidak bermakna, menyebabkan ketakutan, kecemasan, dan kemarahan mereka selama pelajaran. Siswa yang mengatakan matematika sebagai mata pelajaran yang membuat mereka takut, cemas dan bahkan membenci matematika sehingga siswa tidak dapat mengikuti pelajaran matematika atau memiliki kemampuan rendah dan tidak ingin menggali kemampuannya untuk meningkatkan pengetahuan matematikanya, terutama dalam memecahkan masalah (Wahyuddin, 2016).

Dalam hal konteks pembelajaran, kesalahan siswa dimulai dari kesulitan dalam mengonseptualisasikan prinsip-prinsip matematika, kelemahan dalam memformulasi permasalahan dalam bentuk kalimat matematika, penguasaan fakta angka dasar yang tidak lengkap, seperti tabel perkalian, penambahan dan pengurangan sederhana, adalah masalah umum bagi siswa matematika. Fakta angka adalah dasar untuk belajar matematika dan diperlukan untuk memahami konsep yang lebih kompleks. Misalnya, aljabar mengharuskan siswa terlebih dahulu memilah persamaan dasar sebelum masuk pada tahap penyelesaian. Selanjutnya siswa mengalami kelemahan komputasi dalam tugas dan ujian matematika mereka. Contoh kelemahan komputasi termasuk membawa angka yang salah saat perkalian atau pembagian, mentransposisi angka yang salah saat menuliskan jawaban akhir, menuliskan angka di kolom yang salah selama pembagian bahkan salah membaca tanda dan simbol. Salah satu solusi yang dapat ditawarkan untuk menyelesaikan permasalahan tersebut adalah model pembelajaran kooperatif tipe SFAE. Menurut Joyce \& Well bahwa model pembelajaran yang mengaktifkan siswa adalah model interaksi sosial. Adapun model interaksi sosial yang dimaksud adalah model pembelajaran kooperatif (Rusman, 2012).

Pembelajaran kooperatif, tidak seperti pembelajaran kompetitif dan individualistis, siswa bekerja bersama untuk mencapai tujuan bersama. Ini adalah yang paling penting dari ketiga jenis pembelajaran, tetapi paling sedikit digunakan. Siswa akan belajar lebih banyak, lebih senang, lebih menyukai satu sama lain dengan lebih baik, dan belajar keterampilan sosial yang lebih efektif ketika pembelajaran kooperatif digunakan, pernyataan ini didukung dengan kajian empris melaui penelitian terdahulu bahwa ini bukan hanya masalah menempatkan siswa ke dalam kelompok untuk belajar, tetapi interaksi tatap muka yang mendukung akuntabilitas individu dengan melibatkan dan membuat suasana saling ketergantungan positif, serta penggunaan keterampilan interpersonal dan kelompok kecil yang tepat melalaui strategi yang diperlukan untuk menerapkan pembelajaran kooperatif SFAE (Hew \& Cheung, 2008).

Menurut Muslim (2014) bahwa SFAE dirancang untuk mempengaruhi pola interaksi siswa dengan tujuan meningkatkan penguasaan akademik. Dalam implementasinya siswa diberi kesempatan menyajikan serangkaian materi pembelajaran setelah diawali dengan penjelasan secara terbuka oleh guru, dimana kesempatan tersebut digunakan untuk kembali menjelaskan kepada rekan-rekannya sesuai dengan gaya siswa masingmasing.

Kurniasih \& Sani (2016) berpendapat bahwa siswa dapat mempresentasikan ide atau gagasan mereka 
kepada teman-temannya dan melatih siswa dalam hal mengeluarkan pendapatnya sendiri. Menurut Setiawan et al., (2017) bahwa dalam pembelajaran SFAE siswa didorong untuk berani berdebat dalam menjelaskan materi yang dipelajari kepada siswa lain dan buka hanya satu siswa yang mendapat kesempatan melainkan semua siswa akan mendapat kesempatan secara berhiliran. Bayuaji et al. (2017) berpendapat bahwa SFAE memberikan kesempatan bagi siswa untuk memberikan pendapat atau ide dalam memahami suatu masalah. Sebagai kesimpulan bahwa model SFAE menekankan bagaimana siswa dapat mempresentasikan atau memperagakan materi di depan siswa lain.

Terdapat beberapa penelitian yang menjelaskan keefektifan model SFAE diantaranya : (1) Witarsa et al. (2017) dengan hasil penelitian bahwa penggunaan model pembelajaran SFAE mempengaruhi secara signifikan pada kesediaan siswa untuk berbicara saat belajar serta mempengaruhi sikap keberanian untuk berbicara dalam pembelajaran; (2) Mulyono et al., (2018) dengan hasil penelitian bahwa terdapat pengaruh interaksi antara model pembelajaran SFAE dan kemandirian belajar terhadap hasil berestasi dan lajar matematika siswa; (3) Bayuaji et al., (2017) dengan hasil penelitian bahwa terdapat pengaruh model pembelajaran SFAE dengan terhadap hasil belajar siswa; (4) Widayati (2018) dengan hasil penelitian bahwa selama proses pembelajaran dengan strategi SFAE hasil belajar meningkat serta siswa aktif dalam proses pembelajaran dan (5) Anisa et al. (2019) dengan hasil penelitian bahwa model SFAE secara positif mempengaruhi keterampilan sosial pada siswa terutama dalam perilaku asertif. Temuan ini menyiratkan bahwa SFAE adalah metode pembelajaran alternatif untuk meningkatkan perilaku asertif siswa karena menyediakan kesempatan keberanian siswa untuk mencoba mempresentasikan ide atau materi yang merupakan dasil pengembangan ide mereka dari materi awal yang telah disajikan sebelumnya.

\section{METODE PENELITIAN}

Pendekatan penelitian ini yaitu preexperimental design dengan desain one-group pre test-post test design yang merupakan bagian dari penelitian kuantitatif. Penelitian didesain sebagai berikut :

TABEL I

ONE GROUP PRE TEST POST TEST DESIGN

\begin{tabular}{lcc}
\hline Pretest & Treatment & Postest \\
\hline $\mathrm{O}_{1}$ & $\mathrm{X}$ & $\mathrm{O}_{2}$ \\
\hline Sumber : (Sugiyono, 2010) & \\
Keterangan : & \\
$\mathrm{O}_{1}:$ Nilai pretest &
\end{tabular}

$\mathrm{O}_{2}$ : Nilai postest

$\mathrm{X}$ : Perlakuan model.

Satuan eksperimen yaitu siswa kelas VII A.2 yang dipilih secara random dari 4 kelas VII dan dijadikan sebagai kelas perlakuan sebanyak 4 kali tindakan. Instrumen penelitian terdiri atas tes untuk mengukur ketuntasan hasil belajar matematika siswa, aktivitas siswa diukur melalui lembar observasi, respon siswa diukur melaui angket dan lembar observasi keterlaksanaan pembelajaran yang selanjutnya dianalisis melalaui analisis deskriptif dan inferensial dengan one sample t-test yang didahului dengan uji normalitas yang dilanjutkan dengan pengujian hipotesis.

\section{HASIL DAN PEMBAHASAN}

Penelitian ini dilaksanakan dalam 6 kali pertemuan yaitu pre test, perlakuan 4 kali pertemuan, dan post test dengan penjelasan sebagai berikut:

\section{Keterlaksanaan Pembelajaran}

Aktivitas dalam pelaksanaan pembelajaran diamati pada tiga tahapan utama yaitu: bagian pendahuluan, kegiatan inti, dan penutup. Skor rata-rata hasil pengamatan observator selama empat kali pertemuan dari aspek aktivitas guru diuraikan sebagai berikut :

TABEL II

AKTIVITAS KETERLAKSANAAN PEMBELAJARAN

\begin{tabular}{ccc}
\hline Pertemuan & Skor Rata-Rata & Kategori \\
\hline 1 & 3,57 & Sangat Baik \\
2 & 3,71 & Sangat Baik \\
3 & 3,78 & Sangat Baik \\
4 & 3,85 & Sangat Baik \\
Rata-rata & $\mathbf{3 , 7 2}$ & SB \\
\hline
\end{tabular}

Tabel II memberi gambaran bahwa keterlaksanaan pembelajaran setiap pertemuan mengalami progres peningkatan dengan kategori sangat baik. Jadi secara umum keterlaksanaan pembelajaran secara keseluruhan terlaksana sangat baik dengan skor rata-rata sebesar 3,72 .

\section{Deskripsi Hasil Belajar Matematika}

Hasil belajar pre test dan post test diuraikan pada table berikut:

TABEL III

SKOR HASIL BELAJAR SisWA : PRE TEST DAN POST TEST

\begin{tabular}{ccc}
\hline \multirow{2}{*}{ Statistik } & \multicolumn{2}{c}{ Nilai Statistik } \\
\cline { 2 - 3 } & Pre Test & Post Test \\
\hline Unit Penelitian & 15 & 15 \\
Skor Ideal & 100 & 100 \\
Skor Maksimum & 40 & 96
\end{tabular}




\begin{tabular}{ccc} 
Skor Minimum & 16 & 61 \\
Rentang Skor & 24 & 35 \\
Skor Rata-rata & 30,73 & 79,60 \\
Standar Deviasi & 7,67 & 12,11 \\
Modus & $33,35,37$ & 76 \\
Median & 33 & 85 \\
Variansi & 58,92 & 146,68 \\
\hline
\end{tabular}

Selanjutnya dikelompokkan kedalam lima kategori sebagaimana tertuang pada tabel berikut.

TABEL IV

KATEGORI HASIL BELAJAR SISWA : FRE TEST DAN POST TEST

\begin{tabular}{cccccc}
\hline \multirow{2}{*}{ No. } & \multirow{2}{*}{ Kategori } & \multicolumn{2}{c}{ Sebelum } & \multicolumn{2}{c}{ Sesudah } \\
\cline { 3 - 6 } & $\boldsymbol{f}$ & $\boldsymbol{\%}$ & $\boldsymbol{f}$ & $\%$ \\
\hline 1. & Sangat & 15 & 100 & 0 & 0 \\
2. & Rendah (SR) & & & & \\
3. & Sedah (R) & 0 & 0 & 4 & 27 \\
4. & Tinggi (T) & 0 & 0 & 3 & 20 \\
5. & Sangat Tinggi & 0 & 0 & 6 & 40 \\
& (ST) & 0 & 0 & 2 & 13 \\
\hline
\end{tabular}

Interpretasikan tabel IV sebagai berikut.

1) Skor rata-rata pre test sebelum penerapan model kooperatif tipe SFAE adalah 30,73 (kategori sangat rendah) mempunyai nilai maksimum 40 minimum 14, selanjutnya skor rata-rata post tess setelah mengikuti pembelajaran meningkat menjadi 79,60 (kategori sedang) dengan nilai maksimum 96 dan minimum 61. Data ini memberi justifikasi bahwa terjadi peningkatan yang cukup baik dari kategori sangat rendah menjadi kategori sedang.

2) Modus dan median untuk pre test adalah 33 sedangkan post test adalah 88 dan 85 , data ini menunjukkan peningkatan nilai siswa baik nilai median maupun nilai modusnya sehingga terjadi peningkatan hasil belajar siswa secara keseluruhan.

Lebih lanjut, data hasil belajar matematika siswa melaui model pembelajaran kooperaif tipe SFAE dikategorikan berdasarkan kriteria ketuntasan diuraikan pada tabel berikut.

TABEL V

KRITERIA KETUNTASAN HASIL BELAJAR SISWA

\begin{tabular}{ccccc}
\hline & \multicolumn{2}{c}{ Sebelum } & \multicolumn{2}{c}{ Sesudah } \\
Kategori & $\boldsymbol{f}$ & $\mathbf{( \% )}$ & $\boldsymbol{f}$ & $\mathbf{( \% )}$ \\
\hline Tidak Tuntas & 15 & 100 & 4 & 27 \\
Tuntas & 0 & 0 & 11 & 73 \\
Jumlah & 15 & 100 & 15 & 100 \\
\hline
\end{tabular}

Dari tabel V terdapat 15 orang (100\%) siswa tidak memenuhi kriteria ketuntasan individu sebelum diterapkan model dan setelah penerapan model terjadi peningkatan menjadi 4 orang (27\%) tidak tuntas dan 11 (73\%) sudah memenuhi ketuntasan individu. Dimana data tersebut sudah ketuntasan belajar secara klasikal yaitu $\geq 70 \%$.

Selanjutnya data pretest dan postest dianalis dengan normalized gain dan diuraikan pada tabel berikut:

TABEL VI

PENINGKATAN HASIL BELAJAR SISWA

\begin{tabular}{cccc}
\hline Nilai Gain & Kategori & $\mathbf{F}$ & $\mathbf{( \% )}$ \\
\hline $\mathrm{g}<0,30$ & Rendah & 0 & 0 \\
$0,30 \leq \mathrm{g}<$ & Sedang & 7 & 47 \\
0,70 & & & 53 \\
$\mathrm{~g} \geq 0,70$ & Tinggi & 8 & $\mathbf{1 0}$ \\
Jumlah & & $\mathbf{1 0 0}$ \\
Rata-rata & \multicolumn{2}{c}{$\mathbf{0 , 7 0}$} \\
\hline
\end{tabular}

Berdasarkan tabel VI tidak ada siswa memperoleh nilai gain $<0,30$, terdapat 7 atau $47 \%$ siswa dengan nilai gain $0,30 \leq \mathrm{g} \leq 0,70$ (peningkatan kategori sedang) dan 8 atau $53 \%$ siswa dengan nilai gain $\mathrm{g} \geq 0,70$ (peningkatan kategori tinggi). Selanjutnya rata-rata gain ternormalisasi berada pada interval $\mathrm{g} \geq 0,70$ yang berarti bahwa peningkatan hasil pada kategori tinggi.

\section{Hasil Observasi Aktifitas Siswa}

Aktivitas siswa yang diamati selama 4 (empat) kali pertemuan secara ringkas pada tabel berikut:

TABEL VII

REKAPITULASI HASIL OBSERVASI AKTIFITAS SISWA

\begin{tabular}{|c|c|c|c|}
\hline No & Komponen Yang Diamati & Rata", & $(\%)$ \\
\hline \multicolumn{4}{|c|}{ Aktivitas Positif } \\
\hline 1 & $\begin{array}{l}\text { Hadir pada saat proses } \\
\text { pembelajaran berlangsung }\end{array}$ & 14,5 & $97 \%$ \\
\hline 2 & $\begin{array}{l}\text { Siswa menanggapi salam dari } \\
\text { guru dan berdoa bersama }\end{array}$ & 14,5 & $97 \%$ \\
\hline 3 & $\begin{array}{l}\text { Mendengarkan atau } \\
\text { memperhatikan informasi dan } \\
\text { petunjuk-petunjuk dari guru }\end{array}$ & 14,5 & $97 \%$ \\
\hline 4 & $\begin{array}{l}\text { Berani mengajukan diri untuk } \\
\text { menjelaskan materi }\end{array}$ & 6 & $40 \%$ \\
\hline 5 & $\begin{array}{l}\text { Berperan aktif dalam proses } \\
\text { diskusi }\end{array}$ & 14 & $93 \%$ \\
\hline
\end{tabular}


6

Materi yang dipaparkan 5,5 $37 \%$

mudah dipahami dan

disampaikan dengan baik

7 Mengajukan pertanyaan atau memberi tanggapan setelah pemaparan materi

Jumlah

Rata-rata

Aktivitas Negatif

8 Melakukan aktivitas lain pada (ribut, bermain, dsb)

Jumlah

Rata-rata

Dari deskripsi di atas persentase aktivitas positif siswa sebesar $83 \%$ dan persentase aktivitas negatif siswa adalah $17 \%$. Sehingga memenuhi kriteria aktivitas siswa secara klasikal yaitu $\geq 75 \%$ aktif dalam proses pembelajaran.

\section{Respon Siswa}

Data respon siswa yang diperoleh melalui angket selanjutnya dikumpulkan dan dianalisis dan hasilnya disajikan dalam tabel berikut:

TABEL VIII

REKAPITULASI HASIL RESPON SISWA

\begin{tabular}{|c|c|c|c|c|c|}
\hline \multirow{2}{*}{ No } & \multirow{2}{*}{$\begin{array}{l}\text { Komponen } \\
\text { diamati }\end{array}$} & \multicolumn{2}{|c|}{ Ya } & \multicolumn{2}{|c|}{ Tidak } \\
\hline & & $f$ & $(\%)$ & $f$ & $(\%)$ \\
\hline 1. & $\begin{array}{l}\text { Apakah menurut Anda } \\
\text { pelajaran } \\
\text { lebih matematika } \\
\text { dengan menyenangkan } \\
\text { kooperatif tipe student } \\
\text { facilitator } \\
\text { explaining? }\end{array}$ & 10 & $\begin{array}{c}66,6 \\
6 \%\end{array}$ & 5 & $\begin{array}{c}33,3 \\
4 \%\end{array}$ \\
\hline 2. & $\begin{array}{l}\text { Apakah pembelajaran } \\
\text { dengan model Kooperatif } \\
\text { tipe student facilitator } \\
\text { and explaining membuat } \\
\text { anda tertarik dengan } \\
\text { pelajaran matematika? }\end{array}$ & 13 & $\begin{array}{l}86,6 \\
6 \%\end{array}$ & 2 & $\begin{array}{l}13,3 \\
4 \%\end{array}$ \\
\hline 3. & $\begin{array}{l}\text { Apakah Anda } \\
\text { bekerja sama } \\
\text { mengerjakan } \\
\text { matematika? }\end{array}$ & 15 & $\begin{array}{l}100 \\
\%\end{array}$ & 0 & $0 \%$ \\
\hline 4. & $\begin{array}{l}\text { Apakah Anda lebih } \\
\text { termotivasi belajar } \\
\text { matematika setelah } \\
\text { mendapat pembelajaran } \\
\text { dengan model kooperatif } \\
\text { student facilitator and } \\
\text { explaining? }\end{array}$ & 13 & $\begin{array}{l}86,6 \\
6 \%\end{array}$ & 2 & $\begin{array}{l}13,3 \\
4 \%\end{array}$ \\
\hline 5. & $\begin{array}{l}\text { Apakah Anda lebih cepat } \\
\text { memahami pelajaran } \\
\text { matematika dengan } \\
\text { model kooperatif tipe } \\
\text { student facilitator and }\end{array}$ & 13 & $\begin{array}{l}86,6 \\
6 \%\end{array}$ & 2 & $\begin{array}{l}13,3 \\
4 \%\end{array}$ \\
\hline
\end{tabular}

\begin{tabular}{llllll}
\hline \multirow{2}{*}{ No } & $\begin{array}{l}\text { Komponen } \\
\text { diamati }\end{array}$ & yang & \multicolumn{2}{c}{ Ya } & \multicolumn{2}{c}{ Tidak } \\
\cline { 4 - 6 } & & & $f$ & $(\%)$ & $f(\%)$ \\
\hline & explaining? & & & &
\end{tabular}

6. Apakah Anda senang $\begin{array}{lrrrrr}\text { melakukan } & \text { tanya jawab } & & 66,6 & & 33,3 \\ \text { dalam } & \text { belajar } & 10 & 6 \% & 5 & 4 \%\end{array}$ matematika?

\section{Rata-rata}

7. Apakah Anda merasa tegang dan tertekan selama pembelajaran $\begin{array}{llllll}\text { matematika } & \text { dengan } & 6 & 40 \% & 9 & 60 \%\end{array}$ model Kooperatif tipe student facilitator and explaining ?

8. Apakah ada masalah yang Anda temukan dalam belajar matematika dengan model kooperatif tipe student facilitator and explaining?

9. Apakah ada kesulitan yang Anda alami dalam mempelajari materi yang diberikan oleh guru?

$\begin{array}{ll}82, & 17, \\ 21 \% & 79 \%\end{array}$

\begin{tabular}{lll} 
Rata - rata & $\mathbf{5 1 , 1}$ & $\mathbf{4 8 , 8}$ \\
& $1 \%$ & $9 \%$ \\
\hline
\end{tabular}

Berdasarkan Tabel VIII dapat dilihat bahwa untuk pertanyaan positif siswa yang memberi respons positif sebesar 82,21\% dan respon negatif sebesar $17,79 \%$ terhadap pelaksanaan pembelajaran. Selanjutnya dari segi pertanyaan negatif, terdapat $51,11 \%$ siswa yang merasa tegang dan kesulitan dalam belajar dan 48,89 yang merasa tidak tegang dan kesulitan dalam belajar. Sehingga dapat dikatakan efektif karena telah memenuhi kriteria respons siswa yakni $\geq 70 \%$ memberikan respon positif.

\section{Hasil Analisis Inferensial}

Analisis statistik inferensial untuk pengujian hipotesis diawali dengan uji normalitas dan uji gain.

\section{a. Uji Normalitas}

Uji normalitas pre test-post test dengan menggunakan bantuan program komputer dengan program (SPSS) dengan Uji Kolmogorov-Smirnov. Hasil analisis pretest menunjukkan nilai Pvalue $=0,058$ $>\alpha(0,05)$ dan untuk postest menunjukkan nilai $\mathrm{P}$ value $=0,088>\alpha(0,05)$, sehingga disimpulkan bahwa skor pretest dan postest termasuk kategori normal.

b. Pengujian Hipotesis

Pengujian hipotesis dengan uji-t dengan hasil 
berikut:

i) Hasil belajar siswa setelah penerapan dihitung dengan menggunakan uji-t satu sampel diperoleh nilai $\mathrm{t}$ hitung $=12,47 \geq 1,68$. Dengan demikian dapat diiterpretasi bahwa hasil belajar matematika siswa setelah diterapkan model pembelajaran lebih besar atau sama dengan 75 atau mencapai nilai KKM.

ii) Rata-rata peningkatan hasil belajar siswa sebelum dan sesudah tindakan diperoleh nilai thitung $=11,2$ $>$ ttabel $=-2,15$. Dengan demikian peningkatan hasil belajar siswa berada pada kategori sedang dengan nilai gain 0,70 .

iii)Untuk ketuntasan klasikan dengan taraf signifikan $5 \%$ diperoleh $\mathrm{Z}$ tabel $=0,09<\mathrm{Z}$ tabel dan mencapai kriteria ketuntasan lebih $\geq 70 \%$.

Dari hasil analisis data, terjadi peningkatan hasil belajar siswa setelah penerapan model kooperatif tipe SFAE. Lebih lanjut, secara inferensial terdapat perbedaan yang signifikan antara skor pre test dan post test pada taraf signifikansi $5 \%$ yang berarti bahwa setelah diterapkan model SFAE hasil belajar matematika siswa lebih baik.

Keberhasilan yang dicapai tidak terlepas dari penerapan model yang dapat meningkatkan daya serap siswa karena dilakukan melalui demonstrasi, selain itu komunikasi antar anggota kelompok saling mendukung, saling membantu dan suasana belajar yang menyenangkan membuat siswa termotivasi untuk belajar. Lebih lanjut, pelaksanaan pembelajaran memberikan peluang kepada semua siswa untuk berpartisipasi secara individual maupun secara keseluruhan, siswa sebagai disorong menjadi fasilitator dan mendorong siswa berpikir kreatif untuk menghasilkan informasi dari berbagai sumber yang lebih mendalam dan lebih menarik serta meningkatkan kepercayaan diri siswa.

Hasil survei mengungkapkan bahwa setelah penerapan model pembelajaran SFAE siswa lebih energik, memiliki rasa ingin tahu yang tinggi, berkolaborasi dan mengambil tanggung jawab dalam proses pembelajaran karena siswa diundang menjelaskan secara langsung kepada siswa lain, sementara siswa lain dapat memberikan pendapat dan umpan balik pada pikirannya sehingga dapat memahami materi pelajaran, hal tersebut berpengaruh dalam menumbuhkan keberanian peserta didik untuk mengemukakan pendapat secara terbuka.

Penerapan model kooperatif tipe SFAE ini juga dapat menumbuhkan interaksi siswa dalam kegiatan belajar menjadi aktif. Interaksi yang terjadi adalah interaksi multi arah, dari siswa ke guru dan sebaliknya serta siswa ke siswa. Selain itu siswa juga lebih bisa bertukar pendapat secara objektif dalam dalam membahas materi pelajaran yang bermuara pada meningkatkan hasil belajar siswa. Keberhasilan tercapai karena siswa dilibatkan secara aktif sehingga siswa termotivasi dan antusias dalam proses pembahasan materi, siswa dilatih untuk bekerjasama dan saling bertukar pikiran bersama teman kelompoknya dalam menemukan penyelesaian yang ada pada LKS.

Selanjutnya untuk data hasil pengamatan terkait aktivitas siswa dalam pembelajaran menunjukkan data aktivitas kegiatan siswa berada dalam kategori aktif dengan rata-rata persentase aktivitas siswa dalam proses pembelajaran sebanyak $76,42 \%$ atau lebih dari 75\%. Hal tersebut terjadi karena dalam proses pembelajaran siswa dieri kesempatan kesempatan mengeluarkan ide dan pendapatnya sehingga keberanian siswa untuk mencoba mempresentasikan ide atau bahan yang telah dirancang untuk siswa lain.

Hasil penelitian ini mendukung teori Adam \& Mbirimujo, (1990) yang menjelaskan bahwa SFAE merupakan salah satu cara meningkatkan penguasaan beberapa keterampilan siswa diantaranya, keterampilan mendengarkan, keterampilan memahami dalam membaca teks, keterampilan berbicara, keterampilan seni, dan meningkatkan motivasi siswa. Lebih lanjut model pembelajaran kooperatif ini berpusat pada siswa, sebagaimana yang dikemukakan Huda (2013) bahwa kooperatif tipe (SFAE) merupakan kegiatan belajar dengan mempresentasikan serangkaian materi pengajaran yang dimulai dengan penjelasan awal oleh guru secara terbuka, yang selanjutnya memberi kesempatan siswa untuk menjelaskan kembali kepada teman-temannya, dalam pengiriman akhir semua materi disajikan untuk siswa sehingga menumbuhkan motivasi belajar bagi semua siswa. Hal inilah inilah yang memberi dampak positif terhadap peningkatan hasil belajar.

Hal ini sejalan dengan penelitian terdahulu diantaranya: (1) Witarsa et al. (2017) dengan hasil penelitian bahwa penerapan model SFAE mempengaruhi secara signifikan pada kesediaan siswa untuk berbicara mengeluarkan pendapatnya masingmasing pada saat belajar serta mempengaruhi sikap dan keberanian untuk mengeluarkan ide dari hasil analisa yang dilakukan dalam pembelajaran; (2) Mulyono et al. (2018) dengan hasil penelitian bahwa terdapat pengaruh interaksi antara model pembelajaran SFAE dan kemandirian belajar terhadap hasil belajar matematika siswa; (3) Bayuaji et al. (2017) dengan hasil penelitian bahwa terdapat pengaruh model pembelajaran SFAE terhadap hasil belajar siswa; (4) Widayati (2018) dengan hasil penelitian bahwa selama proses pembelajaran dengan strategi SFAE siswa aktif dalam proses pembelajaran dan hasil belajar 
meningkat; dan (5) Anisa et al. 2019) dengan hasil penelitian bahwa Hasil ini menunjukkan bahwa metode SFAE secara positif mempengaruhi keterampilan sosial pada siswa terutama dalam perilaku asertif. Temuan ini menyiratkan bahwa SFAE adalah metode pembelajaran alternatif yang dapat diterapkan untuk meningkatkan perilaku asertif siswa.

Dari hasil analisis respon terdapat $82,21 \%$ siswa memberikan respon positif penerapan model SFAE. Hal ini berarti bahwa pembelajaran matematika melalui model kooperatif tipe SFAE dapat mengakibatkan adanya antusias siswa dalam mempelajari matematika semakin besar karena terjadi perubahan pandangan siswa terhadap matematika dari prasangka yang menakutkan dan membosankan menjadi suatu hal yang menyenangkan karena siswa diberi tanggungjawab melaui keterlibatan secara aktif dalam proses pembelajaran mulai dari awal hingga pembelajaran selesai. Dampak dari hal tersebut, sehingga pengetahuan siswa akan tersimpan lebih lama karena melalui dengan proses dalam menyelsaikan masalah matematika telah dialaminya sendiri.

Berdasarkan hal tersebut diatas dapat disimpulkan bahwa hasil belajar siswa secara individu dan klasikal tuntas, aktivitas siswa mencapai kriteria aktif, serta respon siswa terhadap pembelajaran melalui model kooperatif tipe SFAE positif. Dengan demikian pembelajaran matematika melalui penerapan model kooperatif tipe SFAE efektif diterapkan pada kelas VII SMP Unismuh Makassar. Model pembelajaran ini sangat efektif melatih siswa untuk menemukan dimensi keterampilan yaitu keterampilan berpikir, meneliti, ikut berpartisipasi sosial, dan keterampilan komunikasi serta berbicara dalam menyampaikan ide atau pendapatnya sendiri. Dan dimensi inilah yang yang harus dimemaksimalkan untuk meningkatkan aktifitas proses dan hasil belajar. Sebagaimana penelitian Irlinawati et al. (2013) bahwa model pembelajaran SFAE dapat meningkatkan prestasi belajar peserta didik. Jika dikaitkan antara teori, penelitian terdahulu dan hasil penelitian yang telah dibahas sebelumnya dapat ditarik simpulan bahwa model kooperatif SFAE ini efektif diterapkan dalam pembelajaran matematika.

Partisipasi siswa dalam menunjukkan keberanian dalam berbicara adalah suatu hal yang perlu diperhatikan dan diberikan apresiasi apresiasi dalam proses proses pembelajaran. Belajar akan terasa efektif jika ada komunikasi antara semua elemen dalam proses pembelajaran baik antara siswa dan siswa dan guru dan siswa, sehingga proses pembelajaran harus dirancang agar peserta didik diberikan kebebasan yang lebih besar dalam partisipasi yang menunjukkan beberapa keterampilan sikap dalam berbicara selama proses belajar di kelas

\section{KESIMPULAN}

Penerapan model kooperatif tipe SFAE efektif diterapkan dalam pembelajaran matematika pada siswa kelas VII SMP Unismuh Makassar dengan mengacu pada hasil penelitian sebagai berikut : 1) Hasil belajar matematika siswa setelah diberikan perlakuan berupa pembelajaran dengan model kooperatif tipe SFAE mengalami peningkatan darikategori sangat rendah (ratarata 30,74) meningkat menjadi kategori sedang (rata-rata 79,60) dengan standar deviasi 12,11 dan mencapai ketuntasan belajar secara klasikal; 2) Selama proses pembelajaran aktivitas siswa berada pada kategori aktif yaitu sebanyak 76,42\% siswa; dan 3) Respons siswa terhadap pembelajaran matematika melalui model SFAE memberikan tanggapan positif yaitu sebanyak $82,22 \%$ siswa.

\section{REFERENSI}

Adam, \& Mbirimujo. (1990). Model Pembelajaran. Pustaka Pelajar.

Anisa, R., Mustadi, A., \& Wibowo, U. B. (2019). Student Facilitator and Explaining in Improving Student Social Skills: Assertive Behavior in Opinion and Communication. Advances in Social Science, Education and Humanities Research, 323(ICoSSCE 2018), 309-315. https://doi.org/10.2991/icossceicsmc-18.2019.56

Bayuaji, P., Hikmawati, H., \& Rahayu, S. (2017). Pengaruh Model Pembelajaran Kooperatif Tipe Student Facilitator And Explaining (SFAE) Dengan Pendekatan Saintifik Terhadap Hasil Belajar Fisika. Jurnal Pijar MIPA, 12(1), 15-18. https://doi.org/10.29303/jpm.v12i1.328

Council, N. R. (1989). Everybody Counts: A report to the Nation on the Future of Mathematics Education. National Academy Press.

Hashomoto, Y. (1997). The Methods Of Fostering Creativity Through Mathematical Problem Solving. ZDM, 29(3), 86-88. https://doi.org/https://doi.org/10.1007/s11858-9970005-8

Hew, K. F., \& Cheung, W. S. (2008). Attracting student participation in asynchronous online discussions: A case study of peer facilitation. Computers and Education, $\quad 51(3), \quad 1111-1124$. 
https://doi.org/10.1016/j.compedu.2007.11.002

Huda, M. (2013). Model-model Pengajaran dan Pembelajaran. Pustaka Pelajar.

Irlinawati, D., Efendi, D., \& Andriani, S. (2013). Penerapan Model Pembelajaran Student Facilitator and Explaining Pada Perkalian Bilangan Bulat. Jurnal Pendidikan Matematika STKIP PGRI Sidoarjo, 1(2), 1-12.

Kurniasih, I., \& Sani, B. (2016). Ragam Pengembangan Model Pembelajaran untuk Peningkatan Profesionalitas Guru. Kata Pena.

Livne, N. L. (2008). Enhancing Mathematical Creativity Through Multiple Solution to Open-Ended Problems Online. In National Educational Computing Conference, $1, \quad 1-14$. https://www.researchgate.net/publication/228862669 _ENHANCING_MATHEMATICAL_CREATIVIT Y_THROUGH_MULTIPLE_SOLUTIONS_TO_OP EN-

ENDED_PROBLEMS_ONLINE/link/54e4977a0cf2 dbf60697061c/download

Mulyono, D., Asmawi, M., \& Nuriah, T. (2018). The Effect of Reciprocal Teaching, Student Facilitator and Explaining and Learning Independence on Mathematical Learning Results by Controlling the Initial Ability of Students. International Electronic Journal of Mathematics Education, 13(3), 199-205. https://doi.org/10.12973/iejme/3838

Muslim, S. R. (2014). Pengaruh Penggunaan Metode Student Facilitator And Explaining dalam Pembelajaran Kooperatif terhadap Kemampuan Pemecahan Masalah Matematik dan Kemampuan Berpikir Kritis Matematik Siswa SMK di Kota Tasikmalaya. Jurnal Pendidikan Dan Keguruan, l(1),

https://doi.org/http://jurnal.unsil.ac.id/index.php/jp3 $\mathrm{m} /$ article/view/Sis 11

Rusman. (2012). Model-Model Pembelajaran. Raja Grafindo.

Setiawan, M. A., Budiretnani, D. A., \& Utami, B. (2017). Pengaruh Model Pembelajaran Problem Based Learning Dipadu Student Facilitator and Explaining Terhadap Kemampuan Berpikir Kritis Siswa Kelas X Sman 6 Kediri Pada Pokok Bahasan Fungi. Florea: Jurnal Biologi Dan Pembelajarannya, 4(1), 1. https://doi.org/10.25273/florea.v4i1.1167

Solikhin, \& Mustakim. (2015). Upaya Meningkatkan Keberanian Siswa Bertanya Dan Prestasi Belajar Dengan Pembelajaran Think Pair Share (TPS) Berbantuan Media. Jurnal Pendidikan, 16(2), 74-99. https://doi.org/http://jurnal.ut.ac.id/index.php/jp/artic le/view/337

Sugiyono. (2010). Metode Penelitian Kuantitatif Kualitatif dan $R \& D$. Alfabeta.
Tsafe, A. K. (2012). Effective learning of mathematics: From theory to practice. Sokoto Ediuational Review, 13(2), 82-96. https://doi.org/http://www.sokedureview.org/index.ph $\mathrm{p} / \mathrm{SER} /$ article/view/189

Wahyuddin. (2016). Analisis kemampuan menyelesaikan soal cerita matematika ditinjau dari kemampuan verbal. Suska Journal of Mathematics Education, 9(2), 148-160.

https://doi.org/https://dx.doi.org/10.20414/betajtm.v9i 2.9

Wahyuddin. (2017). Penerapan Model Pembelajaran Numbered Head Together (NHT) Pada Siswa Kelas V Sd Negeri 75 Ujungpero Kecamatan Sabbangparu Kabupaten Wajo. Suska Journal of Mathematics Education, 3(1), 57-66. https://doi.org/http://dx.doi.org/10.24014/sjme.v3i1.23 32

Widayati, R. A. (2018). The Implementation of Cooperative Learning Strategy of Student Facilitator and Explaining (SFE) Type to Improve Activity and Learning Result. Classroom Action Research Journal, 2(1), 13-23. https://doi.org/10.17977/um013v2i12018p13

Witarsa, F. I., Effendi, R., \& Mulyadi, A. (2017). The Effect of Cooperative Learning With Student Facilitator and. International Journal Pedagogy of Social Studies, 2(1). https://doi.org/https://doi.org/10.17509/ijposs.v2i1.865 8 